\title{
De LuZ E DE Sombras: UMA ANÁlise de "O ENFERMEIro", DE Machado de Assis
}

\author{
TÉRCIO REDONDO*
}

RESUMO: $\mathrm{O}$ autor analisa a fina ironia com que o narrador-personagem revela fatos que a sociedade ignora. Um manto de prestígio ou de empatia, por ela outorgado ao cidadão, assegura o ocultamento do gesto mais impiedoso. Desconsideram-se as evidências do mal e o pacto social sobrepõe-se à consciência que ensaiara arrependimento e penitência.

Palavras-chave: Machado de Assis; Sociedade; Indivíduo; Virtude e vício.

O conto "O Enfermeiro" de Machado de Assis se abre e se fecha com disposições testamentárias que enfeixam uma confissão. Procópio, um doente em seu leito de morte, narra em primeira pessoa um episódio de sua vida, antepondo um preâmbulo em que se dirige diretamente a um interlocutor de quem pouco se sabe, interessado na publicaçāo de suas memórias.

Sua história se passa em 1860. Desde o ano anterior, vivia na casa de um padre, antigo companheiro de colégio. Copiava estudos de teologia e recebia, em troca, abrigo e sustento. Chega-lhe então um convite para cuidar de um doente no interior. Enfadado dos textos teológicos e atraído por um bom orde-

(") Médico e pós-graduanđơ em Literatura Alemã na USP. 
nado, aceita de pronto a nova ocupação. O doente, um certo Coronel Felisberto, tem fama de pessoa insuportável e até mesmo violenta. O primeiro contato com o doente confirma essa reputação. Já na apresentação de seu novo enfermeiro, resolve o coronel tratá-lo simplesmente por Procópio, por não gostar de scu sobrenome, Valongo. Iniciam-se as injúrias e, certo dia, ocorre uma agressāo. Procópio resolve deixar o emprego, mas, a pedido do coronel, reconsidera sua decisão. Como a situação volta a se agravar, decide mais uma vez ir embora. Numa noite, quando já cumpria "aviso prévio", na espera de um substituto, é surpreendido pelo coronel que lhe arremessa uma moringa ao rosto. Arroja-se com as mãos ao pescoço do doente. O aneurisma, uma das várias moléstias do coronel, se rompe e ele morre. Depois de uma noite de terror, Procópio resolve ocultar o crime. Encobre e apaga os vestígios da luta. Seguem-se o velório e o enterro. Volta, sem despertar suspeitas, à capital. Após uma semana, recebe a notícia de que o coronel lhe legara todo o seu patrimônio. Isto só faz aumentar o seu remorso. Toma a resolução de doar tudo aos pobres. Os trâmites legais para a apropriação da herança levam alguns meses. Nesse tempo, ouve elogios à sua abnegação e caridade, tanto quanto acusações terriveis ao coronel, homem temido e odiado por sua maldade. Sua disposição inicial já está esmaccida, faz umas poucas esmolas e fica com a maior parte da fortuna.

Voltando ao início do conto, temos um narrador que também trata do patrimônio que legará à posteridade. De início, há um contraste entre a vontade de garantir a divulgação de seu relato e uma atitude aparentemente desinteressada: "Parece-lhe então que o que se deu comigo em 1860 pode entrar numa página de livro?". ${ }^{1}$ Ele apresenta sua história como se fosse objeto de interesse alheio (um pedido para publicação). Esta impressāo será reforçada com a comparação que faz do pequeno texto autobiográfico com a grandiosidade de um império do Gräo-Mogol ou com uma espantosa fotografia dos Macabeus, temas, a seu ver, dignos de entrar nas páginas de um livro de memórias.

Neste ponto, uma fina ironia revela um traço de avareza do enfermo. Diz ao futuro editor de sua história: "peça, porém, os meus sapatos de defunto e não os dou a mais ninguém". Ora, antes de fechar os olhos, o moribundo pode ofertar os astros ou, mais modestamente, todos os seus bens - tudo, menos aquilo que the cabe depois de morto. Defuntos não doam sapatos. Quando muito, oferecem seu corpo à terra. Mas o maior interessado na publicação de suas memórias é o próprio doente-narrador. Elas servem a seus interesses, ainda que solicitadas por um outro. O desejo de divulgar sua história é tão grande que não lhe basta o registro escrito dos acontecimentos. Após passar às mãos de seu interlocutor os manuscritos, inicia um relato oral: "Já sabe que foi em 1860 ...".

Cauteloso, acrescenta a seu testamento cláusulas que o preservam enquanto estiver entre os vivos. Em primeiro lugar, pede que nada venha a público antes de sua morte. Pede, ainda, que se lhe queira bem e que seja perdoado no que "parecer mau". Sua tarefa não será fácil: quererá angariar a simpatia revelando o inconfessável e obter o perdāo sem reconhecer a culpa.

É curiosa a sua maneira de encarar o tempo que se esvai. Compara-o à chama da lamparina de madrugada, ou seja, além de exíguo, o tempo consiste de penumbra. Seu segredo emergirá em meio a luz e sombras, mostrando uma face e escondendo outra. Contente-se o homem com este lúmen que se apaga. O clarão do sol é ilusório, pois o mesmo raio que desnuda todos os contornos ofusca e cega, sendo "impenetrável como a vida". Procópio pede, assim, que (i) MACHADO DE ASSIS, Obra Completa, Rio de Janeiro: Nova Aguilar, 1994, p. 528. 
(2) "Chegando à vila, tive más notícias do coronel. Era homem insuportável, estúrdio, exigente, ninguém $\mathrm{o}$ aturava, nem os próprios amigos. Gaslava mais enfermeiros que remédios. A dous deles quebrou a cara. Respondi que não tinha medo de gente sã, menos ainda de doentes" (MACHADODE ASSIS, op. cit., p. 529)

(1) Alfredo Bosi aponta no Machado pós-Memórias Póstamas o emprego de uma fórmula que esconde "a contradição entre parecer e ser, entre a móscara e o desejo, cntre o rito claro e público e a corrente escusa da vida intcrior". Segundo Bosi, neste esquema machadiano, sobreviver exige uma estreita combinaçāo de interesses do sujeito com a "aparência dominante" (Cf. Alfredo BOSI, A Máscara e a Fendla, in A. BOSI et al., Machado de Assis, São Paulo: Ática, 1982).

(4) "Vindo a hora, fechei o caixāo, com as māos trêmulas, tāo trêmulas que uma pessoa, que reparou nelas, disse a outra com piedade: - Coitado do Procópio! apesar do que padeceu, está muiro sentido" (MACHADO DE ASSIS, op. cit., p. 533). seu ouvinte-leitor se disponha a julgar sua história levando em consideração não somente as aparências (a face visível dos acontecimentos que narra), mas a possibilidade de que um outro lado, ainda obscuro, possa engendrar uma nova versão dos fatos ou uma nova compreenisão de motivos. In dubio pro reo.

Ele não esconde seus interesses pecuniários. Viveu na casa de um amigo padre, não pelo gosto da teologia ou da vida eclesiástica, mas pela oferta de "casa, cama e mesa". Troca, sem pestanejar, essa situação por um bom ordenado, que guarda para dissipar na Corte. Com o intuito de garantir seus proventos, sujeita-se aos caprichos do coronel, a quem serve como enfermeiro, da mesma forma que copiara diligentemente citações latinas que o entediavam. Trata-se de um desocupado de quarenta e dois anos, sem maiores ambições que um posto minimamente remunerado. Parece pouco, mas o salário faz-lhe ignorar avisos $^{2}$ e conviver com sentimentos que embalam o mal no regaço do prazer.

Mas, para Procópio, nāo basta sujeitar-se. É importante que sua postura provoque uma determinada impressão. Ao aceitar que seja tratado simplesmente pelo prenome, obtém de pronto a simpatia do coronel. Em que pese o comportamento invariavelmente mau do doente, parece ter sido esta a imagem que guardou para si de seu enfermeiro, a de um abnegado. Não só o doente: do vigário ao médico, passando por todas as relações do coronel, a opiniāo pública é unânime quanto ao espírito caridoso de Procópio. Indicado por um padre para ocupar as funçōes de enfermeiro, Procópio detém já de início a aura de homem pio. ${ }^{3}$ Trata-se de uma investidura que vem de fora, patrocinada por um representante da Igreja. Procópio jamais reivindicará, ostensivamente, este status. A equação que forma sua imagem é bastante simples: se mesmo os amigos não toleram um contato com o doente que dure mais que uns poucos minutos, Procópio, que o assiste diuturnamente, é um homem santo. Ficam de fora conjecturas a respeito de outros motivos para a sua abnegação.

Em seu espírito digladiam a necessidade do ordenado que acumula e o desejo de logo dissipá-lo na corte. Procópio opta por uma solução de compromisso: vai ficando, conquanto o coronel se abstenha da agressão física ou, mais adiante, por mais um mês à espera de um substituto. O resultado dessa espera insustentável é a morte do coronel. Esta morte, provocada pela fúria de um rancor longamente acumulado, instaura o caos. Procópio vê-se diante de um desastre, uma revoada de pensamentos disparatados e de vozes que o acusam deixam-no aterrorizado e inerte. Passam-se as horas e sobrevém o temor que "complica o remorso". O temor desempenha um papel-chave nos eventos que se seguem, pois exige providências imediatas e traz de volta a serenidade para agir com precisāo e cautela. Ele se sobrepōe ao remorso que deve aguardar melhor oportunidade para se manifestar. O temor dá-lhe a frieza necessária para superar o instinto de fuga que o denunciaria $e$ reassegura o pacto social que o investiu com a aura da virtude. ${ }^{4}$

Procópio leva a sua estratégia de superação do medo até as últimas consequiências e logra um imenso alívio ao ver enterrados juntos o coronel e a punição por seu ato. Está em paz com os homens, resta agora a sua consciência. Seu esquema de redenção moral repetirá de algum modo o que se dera na terrível noite do crime. Há um imperativo, o de "saldar sua dívida", seguido por um período em que ponderações diversas passam a temperar seu ímpeto. Surge, então uma nova solução de compromisso. Sigamos seus passos. 
Consumados todos os preparativos para o enterro (dar a notícia da morte, vestir o defunto, velá-lo), Procópio experimenta um momento de apreensāo: "A passagem da meia-escuridão para a clariclade da rua deu-me grande abalo; receei que fosse então impossível ocultar o crime". 5 A alusão à lamparina no início do conto já antecipara a preferência de Procópio pelo lusco-fusco. Em plena luz do dia, qualquer marca mal escondida do que se dera durante a noite seria fatal. Este incidente é esclarecedor da teoria de Procópio quanto à excelência da penumbra no que diz respeito a um "dọcumento humano". O sol ilumina a verdade pública dos homens. Seu brilho extremo relaciona-se com os fatos que são reconhecidos em uníssono por todos: a piedade de Procópio e o espírito perverso do coronel, bem como a perfídia do assassino, caso um pequeno hematoma escapasse ao colarinho da camisa do finado, denunciando o crime.

Tais verdades nāo interessam a Procópio. São por demais evidentes para merecerem consideração. Não é à toa que a narrativa do que seria o acontecimento capital no conto, a morte do coronel, seja tão sucinta. O narrador ignora quaisquer detalhes da luta: "Não tive tempo de desviar-me; a moringa bateume na face esquerda, e tal foi a dor que não vi mais nada; atirei-me ao doente, pus-lhe as mäos ao pescoço, lutamos e esganei-o"." O que importa é a luta intestina que se trava na alma atormentada do assassino.

De volta ao Rio, Procópio recolhe-se em estado de profunda melancolia. Nada devendo aos homens, vive um luto interior. Manda rezar Missa pela alma do coronel, distribui esmolas e vai vivendo o seu tormento. Até que recebe a incrivel notícia do testamento. Mais uma vez, o mundo da rua e dos homens de que se afastara aparece diante de seus olhos. $O$ impacto da novidade deixa-o atônito, ressurgem os fantasmas de uma cilada para apanhá-lo e as consideraçōes sobre como agir sem despertar suspeitas. Refeito do susto que, sob melhor juízo, revela-se infundado, Procópio livra-se do medo e depara com seu remorso. Retoma então o seu caminho usual nos momentos de impasse. Primeiro, toma uma firme resolução, a de receber a herança e doá-la toda aos pobres.'

Scgue então para a vila. No caminho, atormentam-no ainda as lembranças daquela noite terrível. Busca então atenuantes para seu ato, as humilhações sofridas, a vida do coronel que estava mesmo por um fio. Chega a cogitar de uma coincidência do momento da luta com a morte que já estaria, de antemão, determinada para aquela hora.

Ao chegar, é ungido com as bênçãos do vigário. Na vila todos dão-lhe os parabéns. Mais que isso, seu caráter cristão é contrastado com a impiedade do morto. E Procópio reconhece nas anedotas repletas de sadismo da vida do coronel um veio de prazer "íntimo, calado, insidioso". "Este crescente deleite poderia ser atribuído à economia da dívida. Matara um homem, que afinal das contas merecia morrer. Não era ele, eram os conhecidos do coronel que atestavam a justeza de seu ato. Ocorre que, sentimentos tão indignos quanto os atos do coronel já haviam sido experimentados pelo enfermeiro que perdera sua "escassa dose de piedade" e trazia dentro de si "um fermento de ódio e aversão"." Ambos, coronel e enfermeiro identificam-se na maldade. É a partir deste ponto que o caminho da redenção moral se desfaz. Procópio fica quite com o morto, associando-se com ele naquilo que ambos têm em comum..$^{10} \mathrm{~A}$ virtude promoveria apenas um apaziguamento com os outros homens, algo que já obteve por meio do logro. É o vício que o reconcilia com o morto. Há, portanto, um acerto de contas perverso que não lhe trará a paz, mas oferecerá alívio.
(5) Idem, ibidem, p. 533.

(5) Idem, ibidem, p. 531 .

(n) Notam-se aqui condensados o impulso inicial arrebatador e a solução de compromisso: aceitar os bens para não se trair e doar para se redimir.

(8) MACHADO DE ASSIS, op. cit., p. 534

()) Idem, ibidem, p. 530

(10) São muitas as passagens em que se percebe esta identificação. Ela se dá na própria estrutura do conto que se inicia no 
leito de morte de Procópio, onde se tem um moribundo a falar de outro. Ambos sño velhos $\mathrm{c}$ cuidam de seu legado. São zelosos de suas posses-A primeira pergunta do coronel a seu enfermeiro - "Vocế é gatuno?" - corresponde ì determinação de Procópio que parece dizer: Ninguém vai ficar com aquilo que é neu.

(ii) Danton, a personagem de Büchner, expressa assim este isolamento do homem: "Wasweiss ich? Wir wissen wenig voneinander. Wir sind dickhäuter, wir strecken die Hände nacheinander atur aber es ist vergebliche Mihe, wir reiben nur das grobe Leder aneinander $a b-$, wir sindsehr cinsam" ["Que sei eu? Sabemos pouco um do outro. Nós somos paquidermes, apertamo-nos as mãos, mas é inútil, nós tocamos apenas o couro grosseiro de cada um Somos muito solitários"] (Georg BÜCHNER, Werke und Briefe, München: Deutscher Taschenbuch Verlng, 1988).
Afastada a hipótese da redenção moral, Procópio contabiliza perdas e ganhos e anuncia o saldo no epitáfio que sugere para seu túmulo: "Bem-aventurados os que possuem, porque eles serão consolados". Convém examinar esta posse consoladora. Na gênese de sua fortuna está um patrimônio que vale mais que o dinheiro, uma vez que o antecede como condição prévia à sua aquisição. A aura de virtude que lhe é imposta de fora garante-lhe o emprego como enfermeiro, a simpatia do coronel e o reconhecimento social. Há um abismo que separa suas inclinações mais íntimas c a sua face pública. Uma se apóia na outra enquanto estratégia de sobrevivência, mas ambas jamais coincidem ou se misturam. O que consola Procópio, mesmo sem redimi-lo, é o pacto social que lhe reservou uma posição que sustentará com cocrência até o fim.

No plano social é imperioso ater-se a um determinado papel que até admite alguns improvisos, mas sempre no sentido de reafirmar-se. A personagem nāo se confunde com o ator. Vale dizer, para o indivíduo a sociedade é totalmente estranha, um território em que se transita com facilidade quando se segue o roteiro predeterminado, mas que permanece alheio a tudo o que lhe é mais caro ou decisivo. A vida social empresta ao homem os meios de subsistir. Os desejos mais fundos, a maior alegria e o maior sofrimento mantêm-se alheios à compreensão dos outros. Vive-se essencialmente só." A resolução dos conflitos interiores fica a cargo do indivíduo, de sua vontade e do ponto de equilíbrio que julgar mais conveniente em relação ao mundo externo. Não se trata, para Machado, de hipocrisia. A vida simplesmente não oferece a possibilidade de interagirem dois planos que visceralmente se ignoram.

Procópio faz um testamento em benefício próprio. Seu conteúdo é uma confissão para a qual não há absolvição possível. Resta-lhe comprazer-se ainda uma vez com a impunidade e o lenitivo do dinheiro patrocinado por um juízo social avesso à verdade do indivíduo. Viveu com a admiração e o afeto dos outros aquele que soube ser o mais cruel. O falecido, a despeito de toda a maldade que praticou, teve um gesto de generosidade, deixando todos os seus bens àquele que o amparou em seus últimos dias. Procópio é radical em sua opção pela posse, negando à posteridade até mesmo os seus sapatos.

Assim, a luz do meio-dia que paira sobre o cortejo fúnebre realça a silhueta dos passantes, acentua-lhes a cor e os detalhes do traje. Nada diz do que se tem ou se carrega sob a pele. Somente a tênue chama da lamparina distingue os finos detalhes que compōem a alma humana. Coloque-se também na conta de Procópio este legado de discernimento.

ABstract: The autor analizes the subtle irony employed by the main character, who by means of narrative reveals facts ignored by society. Either to be held in high steem or to be empathized with by society assures one that even his or her harshest actions will be kept hidden. The evidences of evil are not taken into account, and the social order prevails over the conscience which had once considered repetence and penitence.

KEYwords: Machado de Assis; Society; Individual; Virtue And Vice.

Este texto, com ligeiras modificaçōes, foi apresentado como trabalho final do curso de pós-graduação "Métodos e Técnicas de Interpretação e Análise da Obra Literária", ministrado pelo Prof. Davi Arrigucci Jr. no primeiro semestre de 1996. 